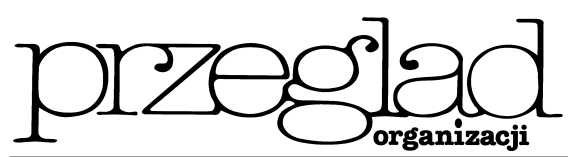

\title{
Likwidacja i odnowa obiektów inwestycyjnych
}

https://doi.org/10.33141/po.2005.78.12

\section{Czesław Sułkowski}

Przegląd Organizacji, Nr 7/8 (786/787), 2005, ss. 47-49 www.przegladorganizacji.pl Towarzystwo Naukowe Organizacji i Kierownictwa (TNOiK)
Określenie przedziału czasowego między momentem rozpoczęcia realizacji inwestycji $(t=0)$ i momentem likwidacji lub odnowy obiektu $(t=n)$ jest często związane z wieloma problemami. Główną przyczyną są trudności z jednoznacznym określeniem długości okresu eksploatacji obiektu inwestycyjnego dla inwestycji realnych.

Określenie długości okresu eksploatacji obiektu może być oparte na wykorzystaniu następujących kryteriów: - trwałości technicznej (fizycznej) obiektu, - ekonomicznie opłacalnej eksploatacji, • użyteczności obiektu.

Ustalenie okresu eksploatacji na podstawie przewidywanej trwałości fizycznej obiektu tylko pozornie jest najprostszym rozwiązaniem. W przypadku obiektu jednoelementowego (budynku, urządzenia, maszyny itp.) można wprawdzie na podstawie parametrów technicznych określić jego trwałość, lecz nie jest to jednak równoznaczne z określeniem właściwego momentu jego likwidacji. Moment ten może być przesuwany w czasie teoretycznie w nieskończoność przez konserwacje i remonty przywracajace w pełni lub tylko częściowo utraconą wartość użytkową obiektu. $\mathrm{Z}$ technicznego punktu widzenia określenie górnej granicy okresu eksploatacji obiektu, jeśli pominąc zużycie nieodwracalne, może więc być bardzo trudne lub zgoła niemożliwe. Trzeba jednak uwzględnić fakt, że koszty związane z opóźnieniem momentu wycofania obiektu z eksploatacji są rosnącą funkcją czasu, co w warunkach posteppu technicznego czyni jego dalsza eksploatację coraz mniej opłacalną. Techniczne kryterium wyznaczania okresu eksploatacji obiektu musi być zatem zastąpione kryterium ekonomicznym, a więc określeniem celowości jego dalszej eksploatacji.

Istotnym elementem, który musi być uwzględniony przy wyznaczaniu okresu eksploatacji, jest okres użyteczności obiektu. O długości tego okresu decyduje popyt na projekty lub usługi obiektu bądź możliwości jego eksploatacji ze względu na czynniki zewnętrzne (na przykład wyczerpywanie się złoża). Czynnik ten, co jest oczywiste, musi być uwzględniony przy wykorzystaniu kryterium ekonomicznego. Przyjmiemy, że będzie to kryterium wartości początkowej netto $(N P V)$.

Problem optymalizacji okresu eksploatacji może być rozważany jako problem optymalizacji momentu likwidacji, bądź optymalizacji okresu odnowy obiektu inwestycyjnego. Dotyczy to zarówno projektów niezależnych, jak również projektów wzajemnie wykluczających się. Różnica polega tylko na tym, że w pierw- szym przypadku problem odnowy może być analizowany, w drugim zaś - musi być analizowany.

Wybór między likwidacją a odnową jest zależny głównie od horyzontu, na jaki firma planuje swoja działalność. Ustalenie okresu eksploatacji na podstawie momentu likwidacji obiektu jest równoznaczne ze stwierdzeniem, że po tym terminie nie ma potrzeby jego dalszej eksploatacji. Jeśli okres ten będzie krótszy niż czas użyteczności obiektu, to problem nie będzie polegał na ustaleniu, kiedy dany obiekt zlikwidować, lecz na określeniu właściwego momentu zastąpienia go nowym obiektem o podobnym lub wyższym poziomie technicznym. W obu przypadkach optymalny okres eksploatacji jest określany przez porównanie korzyści osiąganych w wyniku likwidacji lub odnowy obiektu z korzyściami uzyskiwanymi w wyniku przedłużenia jego eksploatacji o kolejny okres.

Rozważmy problem optymalizacji okresu eksploatacji na podstawie prostej likwidacji. Jeśli projekt wymaga, zaktualizowanych na początek okresu, nakładów inwestycyjnych $I$, przynosić będzie przepływy pieniężne $W_{t}$ na koniec każdego okresu $t$, a jego wartość likwidacyjna w końcu okresu $t=n$ będzie wynosić $L_{n}$, to wyrażając $N P V$ jako funkcję okresu likwidacji otrzymujemy:

$$
N P V(n)=-\mathrm{I}+\sum_{t=1}^{n} \frac{W_{t}}{(1+r)^{t}}+\frac{L_{n}}{(1+r)^{n}}
$$

gdzie:

$N P V(n)$ - wartość początkowa netto dla obiektu, który ma być wycofany z eksploatacji na końcu okresu $t=n$,

$r$ - stopa aktualizacji (koszt kapitału).

Optymalnym okresem eksploatacji będzie ta wartość $n$, dla której $N P V(n)$ osiąga maksymalną wartość. W takim przypadku $N P V(n)-N P V(n-1)>0$ oraz $N P V(n)-N P V(n+1)>0$. Zatem

$$
\begin{gathered}
N P V(n)-N P V(n-1)=\sum_{t=1}^{n} \frac{W_{t}}{(1+r)^{t}}+\frac{L_{n}}{(1+r)^{n}}-\mathrm{I}- \\
-\left(\sum_{t=1}^{n-1} \frac{W_{t}}{(1+r)^{t}}+\frac{L_{n-1}}{(1+r)^{n-1}}-\mathrm{I}\right)=\frac{W_{n}}{(1+r)^{n}}+\frac{L_{n}}{(1+r)^{n}}-\frac{L_{n-1}}{(1+r)^{n-1}}>0
\end{gathered}
$$

a stąd otrzymujemy:

$$
\frac{W_{n}}{(1+r)^{n}}>\frac{L_{n-1}}{(1+r)^{n-1}}-\frac{L_{n}}{(1+r)^{n}}
$$

Nierówność (2) oznacza, że likwidacja obiektu $\mathrm{w}$ końcu okresu $t=n$ jest korzystniejsza niż $\mathrm{w}$ końcu okresu $t=n-1$, jeśli zaktualizowane przepływy pie- 
niężne uzyskane z eksploatacji na koniec okresu $n$ przewyższają różnicę wartości likwidacyjnych obiektu na końcu okresu $n-1$ oraz $n$ zaktualizowanych na początek okresu $(t=0)$. W podobny sposób, uwzględniając, że

$$
\begin{aligned}
N P V(n) & -N P V(n+1)=\sum_{t=1}^{n} \frac{W_{t}}{(1+r)^{t}}+\frac{L_{n}}{(1+r)^{n}}-\mathrm{I}- \\
& -\sum_{t=1}^{n+1} \frac{W_{t}}{(1+r)^{t}}-\frac{L_{n+1}}{(1+r)^{n+1}}+\mathrm{I}>0
\end{aligned}
$$

uzyskujemy

$$
\frac{W_{n+1}}{(1+r)^{n+1}}<\frac{L_{n}}{(1+r)^{n}}-\frac{L_{n+1}}{(1+r)^{n+1}}
$$

Z nierówności (3) można wyciagnać wniosek, że likwidacja obiektu na końcu okresu $t=n$ jest korzystniejsza niż na końcu okresu $t=n+1$, jeśli przepływy pieniężne uzyskane na końcu okresu $n+1$ będą niższe od różnicy wartości likwidacyjnych obiektu w okresie $n$ oraz $n+1$, zaktualizowanych na moment $t=0$.

Można zatem sformułować następującą regułę postępowania: obiekt powinien zostać zlikwidowany na końcu okresu eksploatacji $t(t=1,2, \ldots, n)$, dla którego wartość $t=n$, spełniająca nierówność (2) oraz (3) jest najniższa.

W przypadku projektów wzajemnie wykluczających się ustalenie okresu eksploatacji na podstawie optymalnego okresu likwidacji obiektu nie jest wystarczające*). Projekty te mogą bowiem różnić się długością okresu eksploatacji, a to z kolei uniemożliwia ich bezpośrednią porównywalność. Rozwiązaniem może być tworzenie łańcucha odnowy dla identycznego horyzontu czasowego. Przyjęty w analizie horyzont czasowy może być albo najmniejszą wspólną wielokrotnością okresów eksploatacji analizowanych projektów, albo okresem nieskończenie długim.

Zakładając nieograniczony horyzont działalności obiektu oraz brak zmian w poziomie technicznym nowych urządzeń NPV dla porównywanych projektów można traktować jako funkcję ich nieskończonego łańcucha odnowy. Jeśli ponadto przyjmiemy, że okresy eksploatacji, dla porównywanych projektów inwestycyjnych, zostały określone na podstawie optymalizacji ich okresów likwidacji, czyli spełniają nierówności (2) oraz (3) i wynoszą odpowiednio $n$ oraz $m$, to otrzymujemy:

$$
\begin{aligned}
& N P V(n)=\sum_{t=1}^{n} q^{t} W_{t}+q^{n} L_{n}-I+q^{n}\left(\sum_{t=1}^{n} q^{t} W_{t}+q^{n} L_{n}-I\right)+ \\
& +q^{2 n}\left(\sum_{t=1}^{n} q^{t} W_{t}+q^{n} L_{n}-I\right)+\ldots= \\
& =\left(1+q^{n}+q^{2 n}+\ldots\right)\left(\sum_{t=1}^{n} q^{t} W_{t}+q^{n} L_{n}-I\right),
\end{aligned}
$$

a stąd

$$
N P V(n)=\frac{1}{1-q^{n}} \sum_{t=1}^{n} q^{t} W_{t}+\frac{q^{n} L_{n}}{1-q^{n}}-\frac{I}{1-q^{n}}
$$

Podobnie, dla projektu o okresie odnowy $m$ mamy:

$$
N P V(m)=\frac{1}{1-q^{m}} \sum_{t=1}^{m} q^{t} W_{t}+\frac{q^{m} L_{m}}{1-q^{m}}-\frac{I}{1-q^{m}}
$$

gdzie:

$$
q=\frac{1}{1-r}
$$

Jeśli teraz przez $W_{t}$ oznaczymy przepływy pieniężne netto na końcu okresu $t$, to wyrażenia (4) oraz (5) można sprowadzić do następującej postaci:

$$
\begin{gathered}
N P V(n)=N P V_{n}+q^{n} N P V_{n}+q^{2 n} N P V_{n}+\ldots= \\
=\sum_{t=0}^{\infty} q^{n t} N P V_{n},
\end{gathered}
$$

a stąd

$$
N P V(n)=\frac{N P V_{n}}{1-q^{n}}
$$

Podobnie, dla projektu o okresie eksploatacji (odnowy) $m$ mamy:

$$
N P V(m)=\frac{N P V_{m}}{1-q^{m}}
$$

Warunkiem wyboru projektu o okresie eksploatacji (odnowy) $n$ będzie spełnienie nierówności: $N P V(n)>N P V(m)$, jeśli $N P V(n)>0$.

Przyjęcie stałości elementów rachunku w nieskończonym łańcuchu odnowy można różnie uzasadniać. Niemniej jednak uwzględniając możliwość zmian techniki i technologii, a także - zmian warunków rynkowych, należałoby - o ile jest to praktycznie możliwe analizować efektywność poszczególnych ogniw łańcucha odnowy. Może się bowiem zdarzyć, że wewnętrzna stopa zwrotu dla kolejnych ogniw łańcucha odnowy jest w przybliżeniu równa kosztowi kapitału, a to oznacza, że odnawianie obiektu nie powiększa łącznej wartości miernika NPV. W takim przypadku wzajemnie wykluczające się projekty inwestycyjne można porównywać ignorując różnice w okresach eksploatacji.

Koncepcją, która znalazła stosunkowo szerokie zastosowanie, jest wyznaczenie okresu eksploatacji obiektów na podstawie obowiązujących w danym czasie stóp amortyzacji. W przypadku amortyzacji liniowej okres eksploatacji obiektu równa się odwrotności jego stopy amortyzacji $(s)$, czyli $n=s^{-1}$; oznacza to, że poniesione nakłady inwestycyjne $(I)$ zostaną zwrócone w okresie $n$ lat przez corocznie odkładane raty amortyzacyjne (sn). Zatem

$$
I=n s I \text {. }
$$

W przypadku obiektu wieloelementowego stopa amortyzacji $s$ jest ważoną średnią stóp amortyzacji poszczególnych środków trwałych, a więc jej odwrotność wyraża jedynie umowną, a nie rzeczywistą długość okresu eksploatacji obiektu. Przejście od wartości umownej do rzeczywistej jest możliwe w drodze znalezienia takiego okresu użytkowania obiektu, który jest najmniejszą wspólną wielokrotnością okresów eksploatacji wszystkich tworzących go środków trwałych. Modyfikacją przedstawionej metody ustalania okresu eksploatacji jest koncepcja przyjmująca możliwość kapitalizacji rat amortyzacyjnych. Mamy więc

$$
I=\sum_{t=1}^{n} s I(1+r)^{n-t}
$$

a stąd uzyskujemy poszukiwany okres eksploatacji:

$$
\overline{\mathrm{n}}=\frac{\log \frac{s+r}{s}}{\log (1+r)} .
$$

gdzie: $r$ - stopa aktualizacji.

Przyjęcie stóp amortyzacji jako podstawy do wyznaczania okresów eksploatacji obiektów inwestycyj- 
nych jest, jak się wydaje, oparte na założeniu, że amortyzacja właściwie pełni następujące podstawowe funkcje: • funkcję kosztową, - miernika wartości przenoszonej na produkt oraz funkcję odtworzeniową. Warunkiem koniecznym do prawidłowego pełnienia dwóch pierwszych funkcji jest określenie dla poszczególnych obiektów zużycia względem czasu oraz odpowiadającej jej funkcji utraty wartości obiektu na skutek jego eksploatacji. Na podstawie doświadczenia można sądzić, że będa to raczej funkcje nieliniowe. Wynika stąd wniosek, że ustalenie amortyzacji na podstawie amortyzacji liniowej, jest stosunkowo dużym uproszczeniem.

Kontrowersje może budzić pojmowanie funkcji odtworzeniowej amortyzacji. Przeważa pogląd, że funkcja ta oznacza systematyczne gromadzenie funduszu celem fizycznego odtworzenia (reprodukcji) obiektu. Oznacza to przypisywanie amortyzacji funkcji zwrotu kapitału w jego formie rzeczowej, a nie wartościowej.

W literaturze nie dyskutowano tego problemu w takiej postaci. Rozważano natomiast problem podstawy odpisów amortyzacyjnych, analizując możliwość wykorzystania wartości początkowej lub wartości odtworzeniowej obiektu. Łatwo jest się przekonać, że w istocie rzeczy jest to dyskusja o formie zwrotu kapitału. Teza o konieczności liczenia amortyzacji od wartości odtworzeniowej, będaca w rzeczywistości postulatem zwrotu kapitału w formie rzeczowej, nie może być jednak zaakceptowana w gospodarce rynkowej.

Zauważmy, że rozbieżność między zwrotem kapitału w formie wartościowej i rzeczowej może być usunięta lub zminimalizowana, jeśli w systemie amortyzacji liczonej od wartości początkowej obiektu uwzględni się możliwość kapitalizacji rat amortyzacyjnych, a zmiany nominalnej stopy aktualizacji będą skorelowane ze wskaźnikiem zmian cen.

W gospodarce rynkowej ingerencja państwa w procesy reprodukcji aparatu wytwórczego zazwyczaj odbywa się za pośrednictwem polityki podatkowej. W związku z tym jest możliwe i wielce prawdopodobne, że firmy będą korzystać równocześnie $\mathrm{z}$ dwóch systemów amortyzacji: - oficjalnego, wykorzystywanego do rozliczeń podatkowych z budżetem oraz $\bullet$ wewnętrznego, zapewniającego pożądane tempo zwrotu zainwestowanego kapitału, a więc na podstawie optymalizacji momentu likwidacji lub odnowy obiektu inwestycyjnego.

prof. zw. dr hab. Czestaw Sutkowski Uniwersytet Szczeciński, Politechnika Szczecińska

*) Formułowany w literaturze (LEVY SARNAT, 1994 s. 126) pogląd, że każdy niezależny projekt może być traktowany jako zbiór projektów wzajemnie wykluczających się o różnych okresach odnowy, raczej trudno uznać za uzasadniony.

BIBLIOGRAFIA

[1] CHURCHMAN C.W., ACKOFF R.L., ARNOF E.L., Introduction to Operations Research, John Wiley and Sons, Inc. 1957.

[2] MAO J.C., Quantitative Analysis of Financial Decisions, Macmillan Company 1969.

[3] LEVY H., SARNAT M., Capital Investment and Financial Decisions, Prentice Hall 1994.

[4] SUŁKOWSKI Cz., Decyzje inwestycyjne w zarzadzaniu finansami firm, Wydawnictwo Naukowe Uniwersytetu Szczecińskiego 1996. 